\title{
Online assessment of sand filter performance for bacterial removal in a full-scale drinking water treatment plant
}

Takahiro Fujioka, ${ }^{1, *}$ Tetsuro Ueyama, ${ }^{1,2}$ Fang Mingliang, ${ }^{3}$ Menu Leddy, ${ }^{4}$

${ }^{1}$ Water and Environmental Engineering, Graduate School of Engineering, Nagasaki University, 1-14 Bunkyo-machi, Nagasaki 852-8521, Japan

${ }^{2} R \& D$ division, Kyowakiden Industry Co., Ltd., 10-2 Kawaguchi-machi, Nagasaki 852-8108, Japan

${ }^{3}$ Nanyang Environment \& Water Research Institute (NEWRI), Nanyang Technological University (NTU), 1 Cleantech Loop, CleanTech One, Singapore 637141, Singapore

${ }^{4}$ Essential Environmental Engineering Solutions, Huntington Beach, CA 92649, USA

* Corresponding author: Takahiro Fujioka, Email: tfujioka@nagasaki-u.ac.jp, Tel: +81 095819 2695, Fax: +81958192620 


\section{Abstract}

2 Microbiological risks associated with drinking water can be minimized by providing enhanced

3 integrity monitoring of bacterial removal by water treatment processes. This study aimed to

4 evaluate the efficacy of real-time bacteriological counters for continuously assessing the

5 performance of a full-scale sand filter to remove bacteria. Over the course of an 8-day

6 evaluation, online counting of bacteria was successfully performed, providing continuous

7 bacterial counts in the sand filter influent and effluent over approximate ranges from $17 \times 10^{4}$

8 to $94 \times 10^{4}$ and from $0.2 \times 10^{4}$ to $1.3 \times 10^{4}$ counts $/ \mathrm{mL}$, respectively. Periodic variations were

9 observed with online bacterial counts in the sand filter influent because of the changes in the

10 performance of flocculation and sedimentation processes. Overall, online removal rates of

11 bacteria determined during the full-scale test were 95.2-99.3\% (i.e., 1.3-2.2-log), indicating

12 that online bacterial counting can continuously demonstrate over 1.3-log removal in the sand

13 filter. Real-time bacteriological counting technology can be a useful tool for assessing

14 variability and detecting bacterial breakthrough. It can be integrated with other online water

15 quality measurements to evaluate underlying trends and the performance of sand filters for

16 bacterial removal, which can enhance the safety of drinking water.

17 Keywords: bacterial count; online monitoring; sand filtration; drinking water. 


\section{INTRODUCTION}

20 Management of microbiological risks in drinking water is crucial to ensure the safety of

21 drinking water for public health protection (Villanueva et al., 2014). Microbiological risks in

22 drinking water are typically minimized by achieving a sufficient reduction in pathogenic microorganisms through multiple barriers including drinking water treatment processes (Prest et al., 2016). In a conventional rapid sand filtration system, the filtration process plays a critical role in removing protozoa (i.e., Cryptosporidium and Giardia). Therefore, the United States Environmental Protection Agency (US EPA) has set the Surface Water Treatment Rules (SWTRs), which requires filtration systems to achieve 2-log removal of Cryptosporidium. Nonmicrobial surrogates such as turbidity and/or particle counts are generally used to detect and monitor for waterborne pathogens including Cryptosporidium, because it can be difficult to sample and analyze protozoa at a frequency that can continuously assess sand filter performance for pathogen removal. However, online process monitoring can sensitively and economically detect breakthrough of nonmicrobial surrogates through filtration, this can detect failures for pathogen breakthrough.

As a surrogate indicator of pathogenic contamination in drinking water, total coliform has been widely used as a traditional indicator for water quality. Therefore, the Total Coliform Rule by US EPA sets a drinking water standard (maximum contaminant level goal) for total coliforms at zero cell $/ \mathrm{mL}$. Depending on the concentration of bacteria and inorganic matter, bacteria can be primarily inactivated through post-chlorination. In addition to disinfection, removal of bacteria by sand filtration further enhances the final water quality. To date, online analytical methods have not been fully established with respect to continuous monitoring of sand filter performance for bacterial removal. For monitoring purposes, conventional counting of total culturable bacteria is time consuming and uneconomical. Thus, development of new online real 
time screening methods for microbial contaminants is important to continuously ensure sand

44 filter integrity (Van Nevel et al., 2017; Liu et al., 2018; Sherchan et al., 2018).

45 New technologies for microbial analysis in drinking water applications include flow cytometry (FCM) (Vital et al., 2012; Prest et al., 2014; Samendra et al., 2014; Ou et al., 2017). FCM uses simultaneous light-scattering and fluorescence measurements coupled with dye staining for microbial counting and analysis; thus, bacterial counting using FCM is highly useful to measure microbial water quality. It has been validated for detecting variations in both intact and damaged bacterial cells for drinking water treatment systems and for distribution network (Props et al., 2018). FCM analysis has recently been automated with robotics for staining cells (Hammes et al., 2012; Besmer et al., 2014); providing further capabilities for online monitoring of bacterial counts. However, excessive dye volumes required for staining is a challenge for continuously monitoring sand filter performance.

Another online bacterial counting technique that has recently emerged is a real-time bacteriological counting technology, which is also based on simultaneous light-scattering and autofluorescence measurements (Pepper and Snyder, 2016; Fujioka et al., 2018). This technology utilizes the combined autofluorescence emitted from riboflavin and nicotinamide adenine dinucleotide - hydrogen $(\mathrm{NADH})$ in bacterial cells to identify them in water. By using intrinsic fluorescence, concentrations of bacteria in water can be monitored in real time without dyes for staining and detecting bacteria in water. Thus, online real time bacteriological counters may be more practical for physical treatment processes that provide continuous bacterial counts before and after treatment (Fujioka et al., 2019a; Fujioka et al., 2019b). This technology can

64 be applied to sand filtration to monitor performance for bacterial removal and detect 65 breakthrough of bacteria. Nevertheless, the effectiveness of this approach has not been assessed 66 in drinking water applications. 
67 This study aimed to assess the efficacy of real-time and online bacteriological counting technology for continuously monitoring full-scale sand filter performance for bacterial attenuation and removal. Bacterial counts before and after (i.e., influent and effluent) were continuously measured to demonstrate the ability of online bacterial counting for tracking variations in bacterial removal by sand filter to assess the integrity of the full scale sand filter.

The ultimate aim of this study was to monitor the sand filter and ascertain its performance through online counting of bacteria in the sand filter influent and effluent. Ultimately, online monitoring has the potential of enhancing the safety of drinking water.

\section{MATERIALS AND METHODS}

\subsection{Drinking water treatment system}

This full-scale study was conducted at a drinking water treatment plant in Sasebo (Nagasaki, Japan). This plant is comprised a water intake basin, two rapid mixing basins, four flocculation and sedimentation basins equipped with inclined plate separators, and six rapid sand filtration basins (Fig. 1). Drinking water sources to the plant include both river and lake waters, which are mixed at the water intake basin. Size of each flocculation basin and sedimentation basin is $9.0 \mathrm{~m}(\mathrm{~L}) \times 10.2 \mathrm{~m}(\mathrm{~W}) \times 3.0 \mathrm{~m}(\mathrm{D})\left(\right.$ capacity $\left.=275.4 \mathrm{~m}^{3}\right)$ and $12.0 \mathrm{~m}(\mathrm{~L}) \times 10.4 \mathrm{~m}(\mathrm{~W}) \times 3.0$ $\mathrm{m}$ (D) (capacity $=374.4 \mathrm{~m}^{3}$ ), respectively. Poly-aluminium chloride $(\mathrm{PAC})$ at an $\mathrm{Al}$ concentration of 10.3 w/w\% was supplied by Central Glass Co. (Tokyo, Japan). Each sand filter comprises dual filter media: $0.3 \mathrm{~m}$ depth of anthracite (effective size $=1.2 \mathrm{~mm}$, and uniformity coefficient $=1.4$ ) and $0.35 \mathrm{~m}$ depth of fine sand (effective size $=0.6 \mathrm{~mm}$, and uniformity coefficient $=1.4$ ), which are supported on four gravel layers. Area of each filtration basin is $5.6 \mathrm{~m}(\mathrm{~L}) \times 9.2 \mathrm{~m}(\mathrm{~W})$, which is equal to the surface area of $51.4 \mathrm{~m}^{2}$. 


\subsection{Analytical methods}

91 Real-time bacteriological counters (IMD-W ${ }^{\mathrm{TM}}$, Azbil Co., Tokyo, Japan) were used to monitor

92 bacterial counts in both the influent and effluent of the sand filter. To count the number of bacterial particles, the analyzer detects the intensity of two different lights for particle counting and bacterial autofluorescence in response to the excitation (Ex) light (wavelength $=405 \mathrm{~nm}$ ). The two lights are comprised of (a) scattered light for counting the number and size of particles in water and (b) two autofluorescence emission (Em) lights (wavelength $=410-450$ and 490$530 \mathrm{~nm}$ ) emitted from riboflavin and NADH in bacteria (and protozoa that is larger than bacteria). The analyzer has the capacity of detecting particles of $>0.3 \mu \mathrm{m}$, and requires a sample flow rate of $10 \mathrm{~mL} / \mathrm{min}$ and a water pressure of $>70 \mathrm{kPa}$.

100 Bacterial counting using flow cytometry, epifluorescence microscopy, and plate count was performed using manually collected samples. Flow cytometric bacterial counts were measured using a flow cytometer (BD Accuri ${ }^{\circledR}$ C6, BD Biosciences, San Jose, CA, USA). The analytical instrument was set to irradiate the excitation light (wavelength $=488 \mathrm{~nm}$ ) and to detect emission light through an optical filter (533/30 nm). SYBR Green I nucleic acid gel stain, which is generally used with flow cytometry measurements to count both dead and alive bacteria cells in natural water (Prest et al., 2016), was used for staining bacteria at $1 \%$

107 concentration with 20 min incubation time.

108 Epifluorescent bacterial counts were measured using a fluorescence microscope (Rapisco, 109 Shibasaki, Inc., Chichibu, Japan). Samples were first diluted using pure water. Thereafter, 1 $110 \mathrm{~mL}$ of each sample was filtered using a track-etched polycarbonate MF membrane with $0.2 \mu \mathrm{m}$ 111 pore size (Meric, Tokyo, Japan). Total number of both viable and nonviable bacteria (total

112 direct bacterial counts) was measured with 4'-6-diamidino-2-phenylindole (DAPI) dye 113 solution (Thermo Fisher Scientific, Waltham, MA, USA). Compared to SYBR GREEN 
114 staining, DAPI will generally provide lower bacterial counts; however both methods show a

115 high correlation (Shibata et al., 2007). Alive direct bacterial counts were calculated by

116 subtracting of the dead bacterial cell counts measured using 3,6-Bis(dimethylamino)acridine

117 hydrochloride solution (Dojindo Laboratories, Kumamoto, Japan) from total bacterial counts.

118 Viable bacterial counts were also measured using standard plate count agar (PCA) method.

119 Each sample $(1 \mathrm{~mL})$ was added to $15 \mathrm{~mL}$ sterile standard plate count agar medium (E-KB07,

120 Eiken Chemical, Tokyo, Japan) at a temperature of $45^{\circ} \mathrm{C}$. They were mixed, transferred into 121 sterile Petri dishes, and incubated at $20^{\circ} \mathrm{C}$ for $22-26 \mathrm{hrs}$, as per the Drinking Water Quality

122 Standards in Japan. Bacterial counts using PCA methods were expressed as colony-forming 123 unit (CFU). Heterotrophic plate count (HPC) method was also used to determine the number 124 of total viable bacteria in water that use organic carbon. The HPC method used R2A medium 125 (Kanto Chemical, Tokyo, Japan); plates were incubated at $20-25^{\circ} \mathrm{C}$ and counted after seven 126 days. The other conditions were same as the standard PCA method.

\subsection{Experimental protocols}

128 Sand filter \#3 was evaluated for bacterial removal. Effluent from the sedimentation basin \#2 was collected as the sand filter influent, which was denoted as "filter influent" throughout this study (Fig. 1). Filtrate of the sand filter \#3 was referred as "filter effluent". During the tests,

131 backwashing of the sand filter \#3 was conducted for one hour at 18-19, 90-91, and 162-163

132 hrs. It is important to note that the frequency of backwashing at the full-scale plant during this study period was once every three days, however, throughout the year it can vary depending on the increase in turbidity or the head loss of the filters. To reduce the background interference from dissolved organics (humic acid-like organic matter) that are not counted but can mask autofluorescence of bacteria, an online sample dilution method that was previously reported in

137 literature (Fujioka et al., 2018) was applied. Before analysis, the filter influent and effluent 
underwent 50- and 3-fold dilution using the pure water, respectively (Fig. S1). The pure water was prepared by treating tap water using a reverse osmosis (RO) membrane system followed by a microfiltration (MF) filter. Online bacterial counting of the effluent continued over the course of $184 \mathrm{hrs}$ so that the variations in the bacterial concentration in the raw water matrix and the filter performance were examined for a sufficient period of time. It is noted that online analysis of the filter influent was not performed for the first $17 \mathrm{~h}$. Grab samples for manual water quality analysis were collected once on weekdays (i.e., 17, 41, 65, 89, and $184 \mathrm{hr}$ ). Residual chlorine in the samples $\left(0.3-0.6 \mathrm{mg}-\mathrm{Cl}_{2} / \mathrm{L}\right.$ in the filter influent) was quenched with sodium thiosulphate in the sample bottles. Bacterial log removal was calculated as follows:

$$
\text { Bacterial log removal }=\log _{10} \frac{A}{B}
$$

\section{RESULTS AND DISCUSSION}

\subsection{Online data}

151 Over the course of an 8-day test, variations in the flow rate of raw intake water (approximately between 800 and $1,200 \mathrm{~m}^{3} / \mathrm{h}$ ) occurred because of mixing of lake water from midnight to $2-3$ pm daily (Fig. 2a). The river water was consistently supplied at approximately $800 \mathrm{~m}^{3} / \mathrm{h}$ daily, whereas the lake water was intermittently supplied at approximately $370-400 \mathrm{~m}^{3} / \mathrm{h}$ to meet the increased water demands. According to the intake flow rate, retention time at each flocculation and sedimentation basin at fixed capacity varied from 55-83 and 75-112 min, respectively, which was expected to influence their treatment performance. Coagulation with PAC was performed at a constant coagulant dose of 6.3-8.8 mg-A1/L (Fig. S2a). After the sedimentation process, the effluent underwent intermediate chlorination with a constant hydrochloric acid

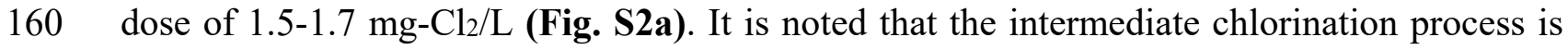


mainly designed to minimize the growth of algae and bacteria in the sand filter basin. The flow rate at sand filter \#3 ranged from 1.7 to $4.8 \mathrm{~m}^{3} / \mathrm{m}^{2} \mathrm{~h}$ according to the changes in intake flow rate and backwashing of the other filtration basins (Fig. S2b). During the testing period, turbidity before the sand filter varied in the range of $0.3-1.5 \mathrm{mg} / \mathrm{L}$ almost every $12 \mathrm{hrs}$ (Fig. S3a). Accordingly, turbidity in the filter effluent varied from 0.01 to $0.06 \mathrm{mg} / \mathrm{L}$ (Fig. S3b).

167 During the evaluation, online bacterial counts in the filter influent considerably varied from $16817 \times 10^{4}$ to $94 \times 10^{4}$ counts $/ \mathrm{mL}$ (Fig. 2 b). This occurred at the same frequency as the variation in intake flow rate (Fig. 2). The variable intake flow rate can change the retention time of the water in the flocculation and sedimentation basins, which is directly linked with the efficiency of floc formation and sedimentation and can vary the bacterial counts in the effluent (i.e., filter

172 influent). Online bacterial counts in filter effluent were low, ranging from $0.2 \times 10^{4}-1.3 \times 10^{4}$

173 counts $/ \mathrm{mL}$; this was approximately two orders of magnitude lower than those in the filter influent (Fig. 2b). In general, online bacterial counts in the filter influent showed an underlying downward trend, whereas those in the filter effluent did not follow the trend. In response to the periodical changes in intake flow rate, online bacterial counts in both influent and effluent varied periodically. Additionally, a sudden increase of bacterial counts in the filter effluent was observed after backwashing of sand filter \#3 at 18-19, 90-91, and 162-163 hrs. As previously reported, a similar increase in residual turbidity in the filter effluent after backwashing can be found in drinking water applications (Ahmad et al., 1998). Following backwashing, the breakthrough of bacteria in the sand filters can occur due to direct pass through and release of

182 bacteria retained on sand particles. Bacteria, which were not removed by backwashing (i.e.,

183 bacteria retained between sand particles), are more likely to pass through the sand filters, causing the sudden increase in bacterial counts soon after backwashing. Overall, the results 
here showed that online bacterial monitoring can detect variations and track the overall trends in bacterial counts in the filter influent and effluent. This indicates that online bacterial monitoring can be used as a sensitive tool for rapidly detecting bacteria-related issues such as spikes and breakthrough.

\subsection{Manual bacterial counts}

190 To assess the variance among bacterial counting techniques and identify the level of microbial 191 contaminant in the filter effluent, microbial water quality analysis with additional methods (i.e., 192 epifluorescence microscopy, flow cytometry, PCA, and HPC) was conducted using manually 193 collected samples at five different sampling events. In the filter influent, the epifluorescent counts that measure the total bacterial counts $\left(27 \times 10^{4}-82 \times 10^{4}\right.$ counts $\left./ \mathrm{mL}\right)$ and alive bacterial counts $\left(8 \times 10^{4}-26 \times 10^{4}\right.$ counts $\left./ \mathrm{mL}\right)$ were similar to the online bacterial counts recorded at the time of sample collection $\left(43 \times 10^{4}-89 \times 10^{4}\right.$ counts $\left./ \mathrm{mL}\right)$ (Table S1). However, a clear

197 correlation between the two parameters was not established (Fig. 3a). Similarly, flow 198 cytometric bacterial counts in the filter influent $\left(7 \times 10^{4}-16 \times 10^{4}\right.$ counts $\left./ \mathrm{mL}\right)$ showed no correlation with the online bacterial counts. Conventional bacterial counting with the PCA and HPC methods showed lower bacterial counts (22-77 and 650-1,700 CFU/mL, respectively) than the online bacterial counts in the filter influent. The difference in counts between the methods is typically found in surface water; the total bacterial community by HPC can be down to $0.001-8.3 \%$ of total direct bacterial counts (Van Nevel et al., 2017). In the filter effluent, the online bacterial counts $\left(0.6 \times 10^{4}-1.3 \times 10^{4}\right.$ counts $\left./ \mathrm{mL}\right)$ were greatly reduced than the epifluorescent counts for total bacterial $\left(6.3 \times 10^{4}-13.6 \times 10^{4}\right.$ counts $\left./ \mathrm{mL}\right)$ and alive bacteria $\left(1.5 \times 10^{4}-4.5 \times 10^{4}\right.$ counts $\left./ \mathrm{mL}\right)$ but similar to flow cytometric bacterial counts $\left(0.2 \times 10^{4}-1.0 \times 10^{4}\right.$ counts/mL) (Table S1). Among the results, online bacterial counts showed a relatively high correlation with total direct bacterial counts $(r=0.93)$ and flow cytometric bacterial counts $(r$ 
$209=0.85$ ) (Fig. 3b). Results showed that online bacterial counts in the filter influent are generally

210 not well correlated with those by other conventional and emerging methods. This is likely due

211 to the fundamental difference in the principle of bacterial counting among these techniques.

212 Real-time bacteriological counter identifies most bacteria $(>0.2 \mu \mathrm{m})$ but relies on the

213 autofluorescence intensity of bacteria. It is not fully established whether all alive bacterial cells

214 are counted, because autofluorescence of bacteria can be varied for various reasons such as cell

215 viability. In this study, alive bacterial counts did not show a significant correlation with online

216 bacterial counts for both filter influent and effluent either. Therefore, for future studies, it is

217 important to identify what state of bacteria is actually counted by online bacterial counter and

218 whether there is an algorithm (e.g., the ratio between two autofluorescent metabolites) to

219 deconvolute the alive and dead cells.

[Fig. 3]

\subsection{Variations in bacterial removal rate}

222 Online bacterial counts in both the filter influent and effluent throughout the full-scale test provided bacterial removal rates over the ranges from $95.2 \%$ to $99.3 \%$, which corresponds to removal rates of 1.3-2.2-log (Fig. 4). Bacterial removal rates showed an underlying downward trend during filtration. Daily fluctuations in log removal rate appeared to be associated with the fluctuation in online bacterial counts in the filter influent, however, this was not considerable. More importantly, despite the remarkable increase in bacterial counts in the filter effluent after each backwashing event, log removal rate dropped only slightly from 2.16- to $1.95-\log$, from 1.93- to $1.68-\log$, and from $1.68-$ to $1.56-\log$ for the backwashing at 18,90 , and $162 \mathrm{hr}$, respectively; indicating backwashing with sufficient drain prior to restart of sand filtration ensures the filter water quality. Further data analysis indicated that there was a $90 \%$ probability

232 that the bacterial log removal rates range between 1.5-2.0-log (Fig. 5). The performance 
233 distribution curve was relatively broad with the average and standard deviation of 1.7-log and

234 0.2-log, respectively. These findings demonstrate that real-time bacteriological counting 235 technology can be useful for monitoring the sand filter process and its ability to remove 236 bacterial contaminants. The online monitoring technology has the potential of continuously 237 demonstrating approximately a 1.5-log removal of bacteria by the sand filtration process. 238 Additionally, the results demonstrate that continuous monitoring of bacterial counts before and 239 after sand filtration provides a profile of the variation in the counts and the underlying trends 240 in bacterial removal by the sand filtration process, which cannot be determined otherwise.

243 The cause and effect of the variations in bacterial removal rate during the full-scale

244 performance tests was beyond the scope of this study. The size and shape of bacteria and 245 biofilm formation on the sands can be an important properties for determining the extent of 246 their removal during the filtration process (Kristian Stevik et al., 2004; Bai et al., 2016);

247 bacteria larger than $1 \mu \mathrm{m}$ size are more likely to be retained by the sand filtration process 248 (Gannon et al., 1991). Additionally, the community composition of bacterial species can vary 249 considerably daily and seasonally. In addition, microbiomes in drinking water are very 250 complex with up to forty eight (48) phyla including predominant Protebacteria (Proctor and 251 Hammes, 2015). Next-generation DNA sequencing of 16S rRNA (Liu et al., 2018) can help 252 identify which bacterial species are passing through the sand filter.

\section{$253 \quad 3.4 \quad$ Full-scale implications}

254 Real-time bacteriological counting technology can provide online measurements of bacterial counts, which can be integrated with conventional online water quality measurements (i.e., 
turbidity) to enhance the safety of drinking water. Collection of online measurements during individual filter operation establishes operational baselines for bacterial counts in the filter influent and effluent, and provides a more accurate assessment of bacterial removal rates. The range and variation in bacterial counts during the earlier stages of the treatment process can

260 help to detect spikes and unacceptable breakthrough of bacteria in a drinking water treatment systems during minimal incremental failure. This information can act as an early warning that necessitates to implement countermeasures such as increasing coagulation and/or disinfection.

263 Determining the baseline level of bacterial counts at each treatment process provides greater 264 information to investigate the cause of unexpected events in microbial water quality by 265 analyzing historical data. In addition, baseline bacterial counts and removal rates can help to 266 detect failures and changes in the separation performance and integrity of sand filter process.

267 Compared to turbidity as a classical surrogate indicator for bacterial contamination, bacterial count is more relevant to microbial quality. Thus, in addition to conventional turbidity monitoring, online bacterial monitoring for bacterial removal can enhance the safety of 270 drinking water.

271 Bacterial removal by sand filter has the potential to be used as a surrogate for controlling sand

272 filter process for the removal of protozoa (e.g. Cryptosporidium and Giardia). The removal of bacteria and protozoa by sand filtration is dependent upon size exclusion mechanisms along with other mechanisms such as adsorption and sedimentation. Thus, the removal of protozoa $(>1 \mu \mathrm{m}$ in size) can be expected to be greater than bacteria $(>0.2 \mu \mathrm{m}$ in size) because of size.

276 Because the performance of full-scale media filtration processes for bacterial removal can be 277 variable depending on the conditions of the filter (e.g., clogging level, backwashing, and effective media size), the enhanced integrity monitoring for protozoa removal at each filter basis can improve the safety of drinking water. Further sand filtration studies are needed to 
verify the use of bacterial removal as a surrogate of protozoa removal through long-term fullscale evaluations.

282

283

284 285

286

\section{Conclusions}

This study for the first time assessed the efficacy of real-time bacteriological counters for continuously and economically measuring bacterial counts in the sand filter influent and effluent at a full-scale drinking water treatment plant. Bacterial counts in the sand filter influent and effluent were continuously determined over approximate ranges from $17 \times 10^{4}$ to $94 \times 10^{4}$ and from $0.2 \times 10^{4}$ to $1.3 \times 10^{4}$ counts $/ \mathrm{mL}$, respectively. Online bacterial counts in the filter influent and effluent varied in response to changes in flow rate and backwashing. Online removal rates of bacteria determined during the full-scale test were 1.3-2.2 log (i.e., 95.299.3\%). This indicates that online bacterial counting can continuously demonstrate over 1.3$\log$ removal in sand filter performance. This also suggests that online bacterial monitoring can be a useful tool to ascertain log removal rates by sand filtration process. Monitoring the bacterial removal rates can be integrated with conventional online water quality measurements in sand filter effluent (e.g., turbidity and particle counts) to enhance the safety of drinking water.

\section{ACKNOWLEDGEMENT}

The authors thank Ms. Anh Tram Hoang (Nagasaki University) for her help on epifluorescence microscopy and Mr. Ryo Makabe and Mr. Kei Matsuyama (Kyowakiden Industry Co.) for their help on flow cytometric analysis. The authors also acknowledge Azbil Corp. for loaning realtime bacteriological monitors.

\section{REFERENCES}

Ahmad, R., Amirtharajah, A., Al-Shawwa, A., Huck, P.M., 1998. Effects of backwashing on biological filters. Journal - American Water Works Association 90, 62-73. 
Bai, H., Cochet, N., Pauss, A., Lamy, E., 2016. Bacteria cell properties and grain size impact on bacteria transport and deposition in porous media. Colloids Surf. B. Biointerfaces $139,148-155$.

Besmer, M.D., Weissbrodt, D.G., Kratochvil, B.E., Sigrist, J.A., Weyland, M.S., Hammes, F., 2014. The feasibility of automated online flow cytometry for in-situ monitoring of microbial dynamics in aquatic ecosystems. Frontiers in Microbiology 5, 265.

Fujioka, T., Hoang, A.T., Aizawa, H., Ashiba, H., Fujimaki, M., Leddy, M., 2018. Real-Time Online Monitoring for Assessing Removal of Bacteria by Reverse Osmosis. Environ. Sci. Technol. Letters 5, 389-393.

Fujioka, T., Hoang, A.T., Ueyama, T., Nghiem, L.D., 2019a. Integrity of reverse osmosis membrane for removing bacteria: new insight into bacterial passage. Environ. Sci.: Water Res. Technol. 5, 239-245.

Fujioka, T., Makabe, R., Mori, N., Snyder, S.A., Leddy, M., 2019b. Assessment of online bacterial particle counts for monitoring the performance of reverse osmosis membrane process in potable reuse. Sci. Total Environ. (In Press, 10.1016/j.scitotenv.2019.02.339).

Gannon, J.T., Manilal, V.B., Alexander, M., 1991. Relationship between Cell Surface Properties and Transport of Bacteria through Soil. Appl. Environ. Microbiol. 57, 190193.

Hammes, F., Broger, T., Weilenmann, H.-U., Vital, M., Helbing, J., Bosshart, U., Huber, P., Peter Odermatt, R., Sonnleitner, B., 2012. Development and laboratory-scale testing of a fully automated online flow cytometer for drinking water analysis. Cytometry Part A 81A, 508-516.

Kristian Stevik, T., Kari, A., Ausland, G., Fredrik Hanssen, J., 2004. Retention and removal of pathogenic bacteria in wastewater percolating through porous media: a review. Water Res. 38, 1355-1367.

Liu, G., Zhang, Y., van der Mark, E., Magic-Knezev, A., Pinto, A., van den Bogert, B., Liu, W., van der Meer, W., Medema, G., 2018. Assessing the origin of bacteria in tap water and distribution system in an unchlorinated drinking water system by SourceTracker using microbial community fingerprints. Water Res. 138, 86-96.

Ou, F., McGoverin, C., Swift, S., Vanholsbeeck, F., 2017. Absolute bacterial cell enumeration using flow cytometry. J. Appl. Microbiol. 123, 464-477.

Pepper, I.L., Snyder, S.A., 2016. Monitoring for reliability and process control of potable reuse applications. Water Environment \& Reuse Foundation and IWA Publishing, Alexandria, VA.

Prest, E.I., El-Chakhtoura, J., Hammes, F., Saikaly, P.E., van Loosdrecht, M.C.M., Vrouwenvelder, J.S., 2014. Combining flow cytometry and 16S rRNA gene pyrosequencing: A promising approach for drinking water monitoring and characterization. Water Res. 63, 179-189. 
Prest, E.I., Hammes, F., van Loosdrecht, M.C.M., Vrouwenvelder, J.S., 2016. Biological Stability of Drinking Water: Controlling Factors, Methods, and Challenges. Frontiers in Microbiology 7, 1-24.

Proctor, C.R., Hammes, F., 2015. Drinking water microbiology-from measurement to management. Curr. Opin. Biotechnol. 33, 87-94.

Props, R., Rubbens, P., Besmer, M., Buysschaert, B., Sigrist, J., Weilenmann, H., Waegeman, W., Boon, N., Hammes, F., 2018. Detection of microbial disturbances in a drinking water microbial community through continuous acquisition and advanced analysis of flow cytometry data. Water Res. 145, 73-82.

Samendra, P.S., Masaaki, K., Charles, P.G., Ian, L.P., 2014. Rapid Detection Technologies for Monitoring Microorganisms in Water. Biosensors Journal 3, 109.

Sherchan, S., Miles, S., Ikner, L., Yu, H.-W., Snyder, S.A., Pepper, I.L., 2018. Near Real-Time Detection of E. coli in Reclaimed Water Sensors 18, 2303.

Shibata, A., Imai, A.K.I., Hara, S., Kikuchi, T., Toda, T., Taguchi, S., 2007. Quantitative difference in bacterial abundance determined with each protocol for SYBR Green I and 4'6-diamidino-2-phenylindole (DAPI) methods. Plankton and Benthos Research 2, 6366.

Van Nevel, S., Koetzsch, S., Proctor, C.R., Besmer, M.D., Prest, E.I., Vrouwenvelder, J.S., Knezev, A., Boon, N., Hammes, F., 2017. Flow cytometric bacterial cell counts challenge conventional heterotrophic plate counts for routine microbiological drinking water monitoring. Water Res. 113, 191-206.

Villanueva, C.M., Kogevinas, M., Cordier, S., Templeton, M.R., Vermeulen, R., Nuckols, J.R., Nieuwenhuijsen, M.J., Levallois, P., 2014. Assessing exposure and health consequences of chemicals in drinking water: current state of knowledge and research needs. Environ. Health Perspect. 122, 213-221.

Vital, M., Dignum, M., Magic-Knezev, A., Ross, P., Rietveld, L., Hammes, F., 2012. Flow cytometry and adenosine tri-phosphate analysis: Alternative possibilities to evaluate major bacteriological changes in drinking water treatment and distribution systems. Water Res. 46, 4665-4676. 


\section{FIGURES}

Fig. 1 - Schematic flow diagram of the drinking water treatment plant.

Fig. 2 - (a) Flow rate of raw water intake and (b) online bacterial counts in the filter influent and effluent (Data recorded for 5 min was averaged and plotted. Backwashing was conducted for one hour at 18-19, 90-91, and 162-163 hrs).

Fig. 3 - Bacterial counts determined by epifluorescent microscopy and flow cytometry as a function of online bacterial counts in the (a) filter influent and (b) filter effluent. Error bars show standard deviations for analytical triplicates.

Fig. 4 - Bacterial removal rates as determined by online bacterial counters. Backwashing was conducted for one hour at 18-19, 90-91, and 162-163 hrs.

Fig. 5 - Process performance probability distribution of bacterial removal rates as determined by online bacterial counters (Average $=1.7-\log , \mathrm{STDEV}=0.2-\log$ ). 


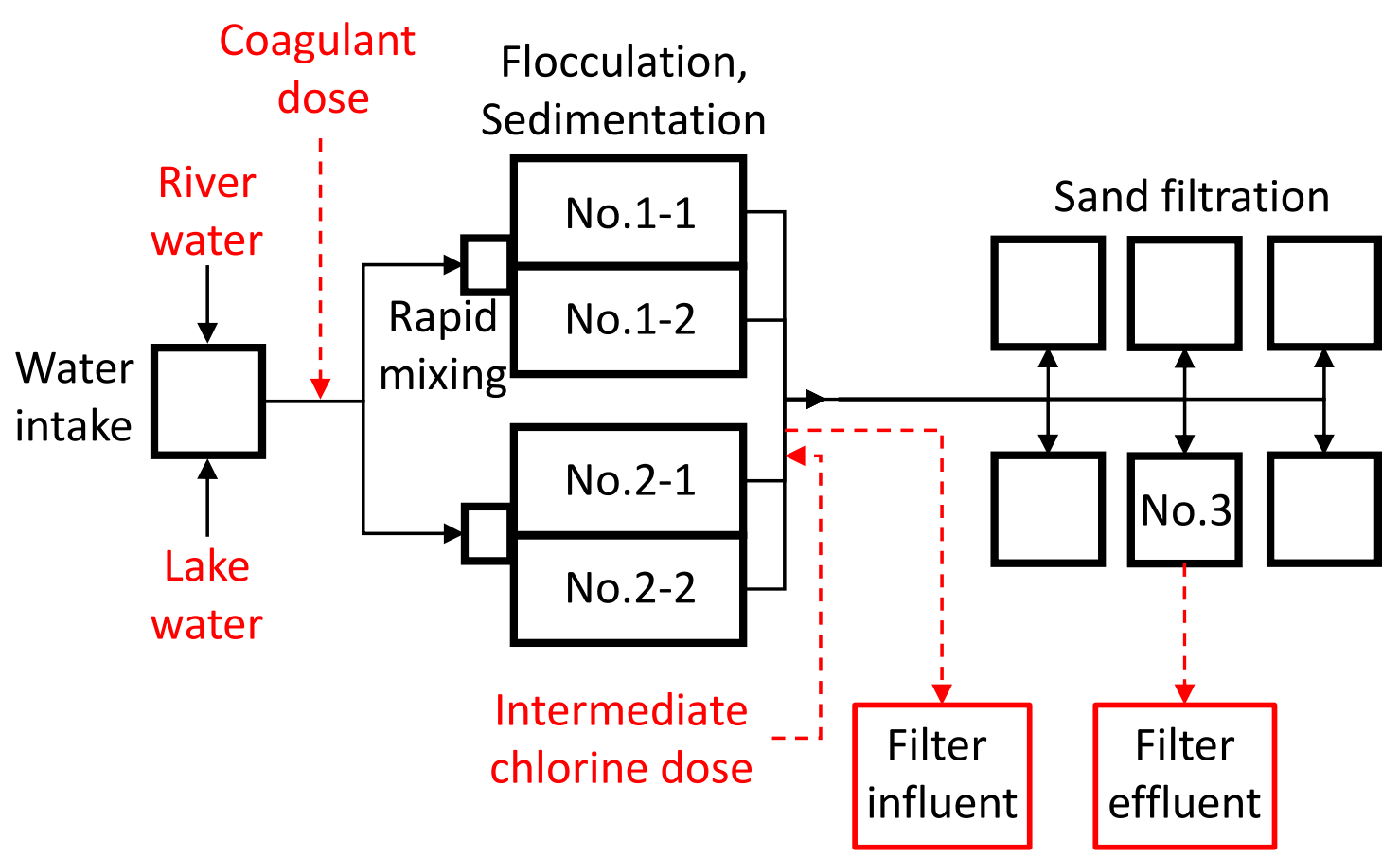

Fig. 1 


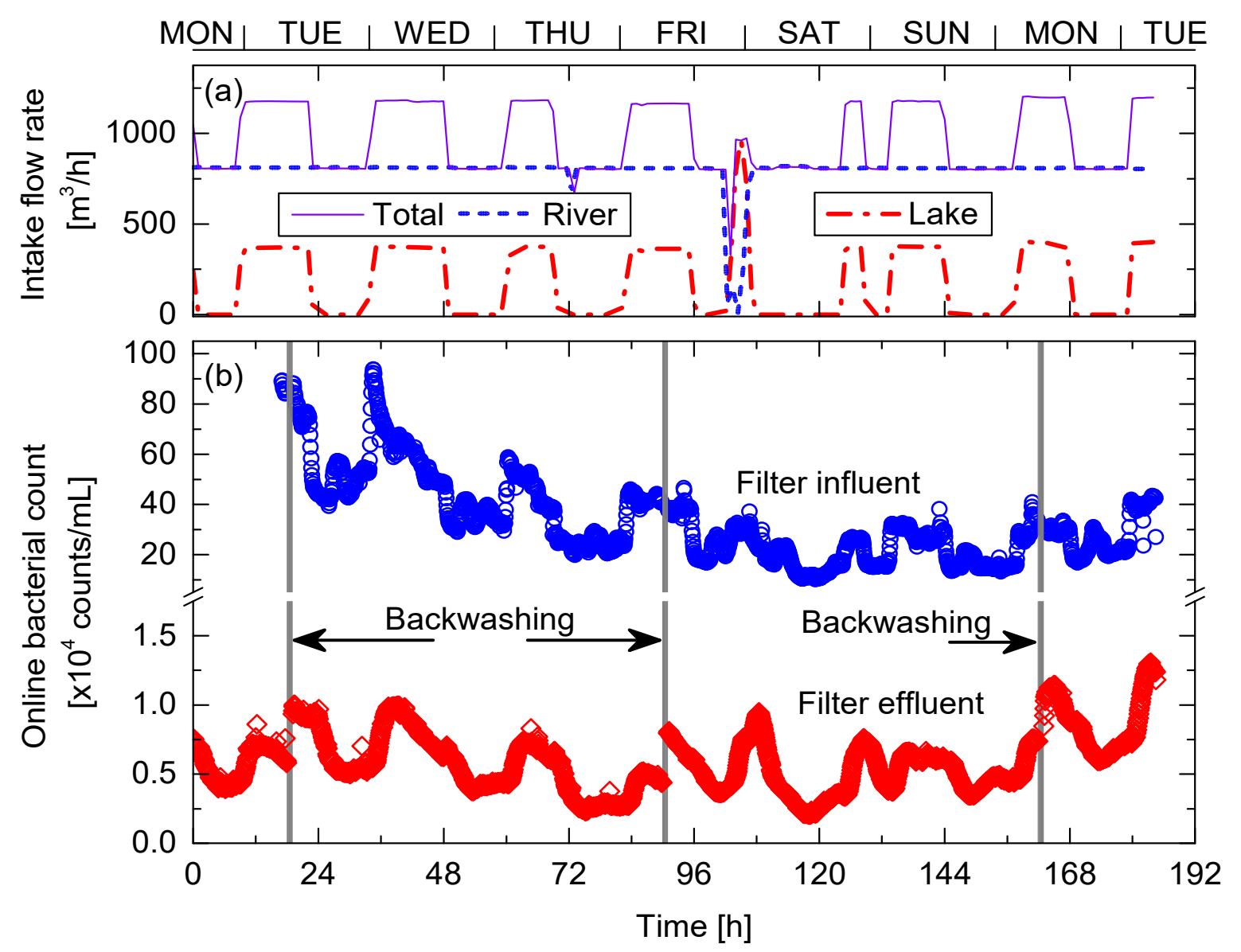

Fig. 2 

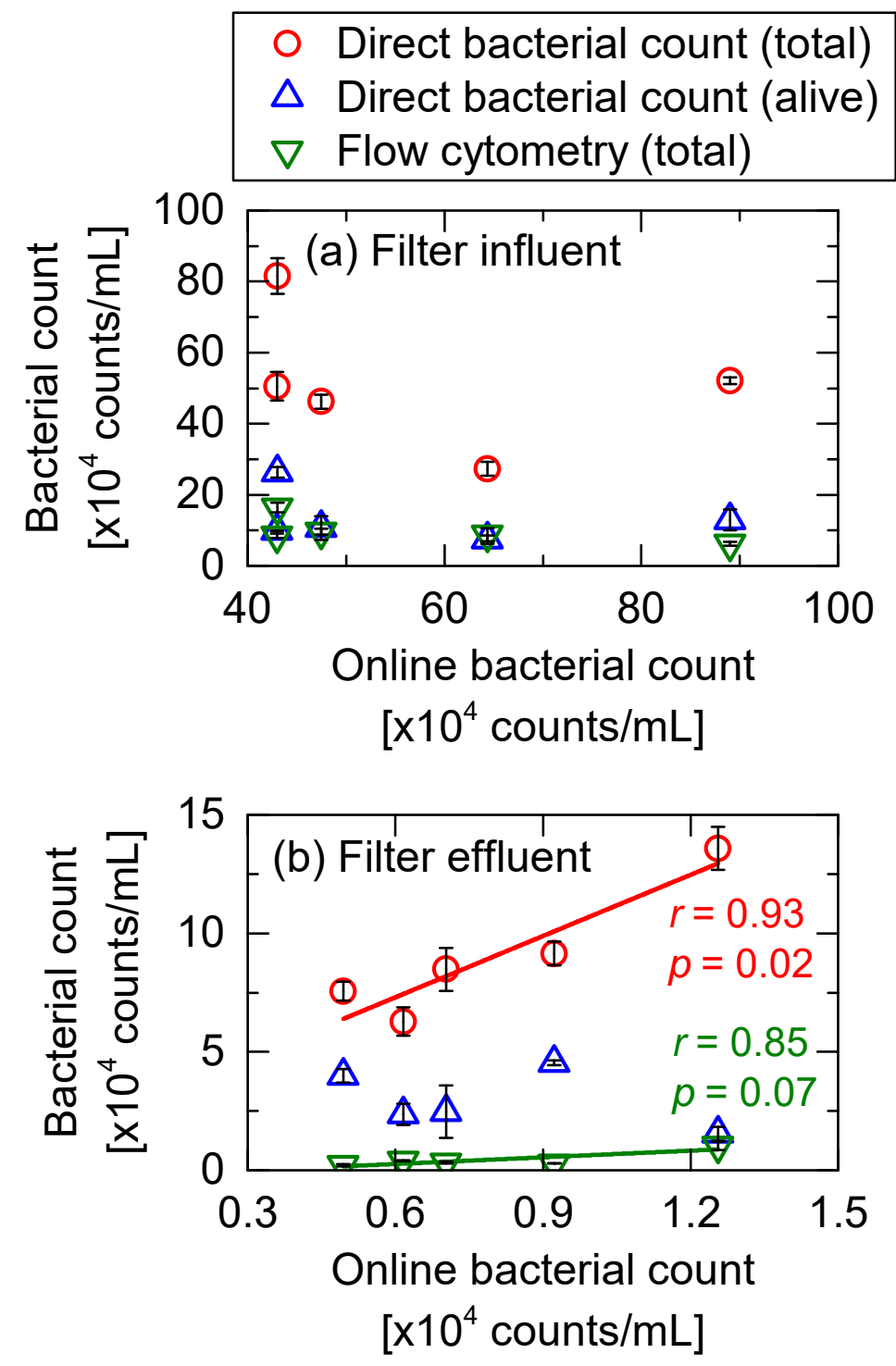

Fig. 3 


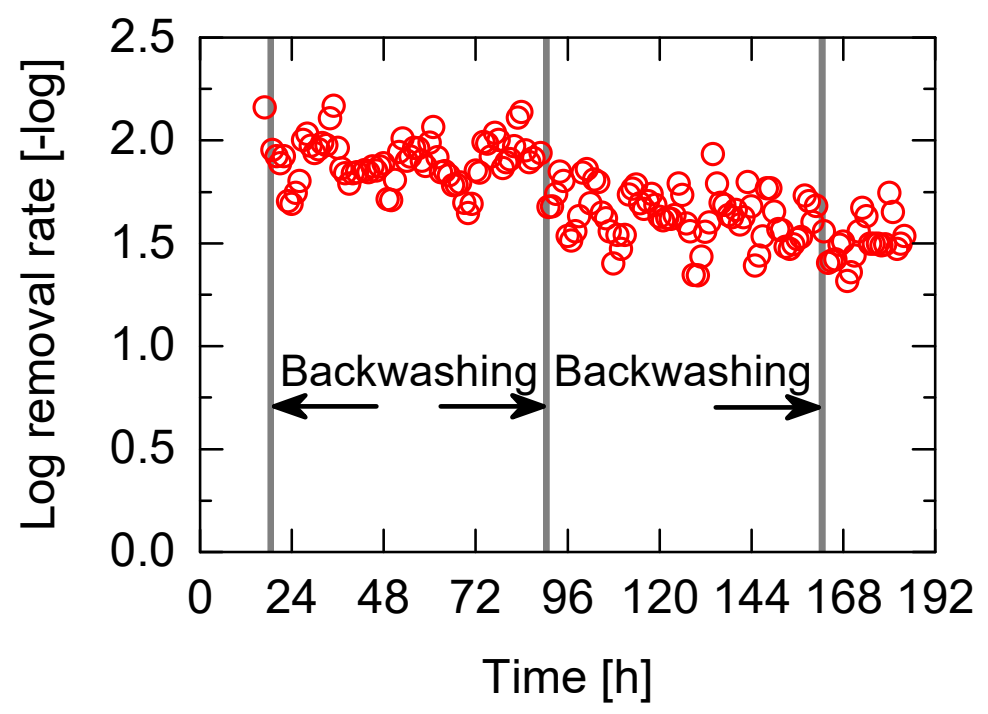

Fig. 4 


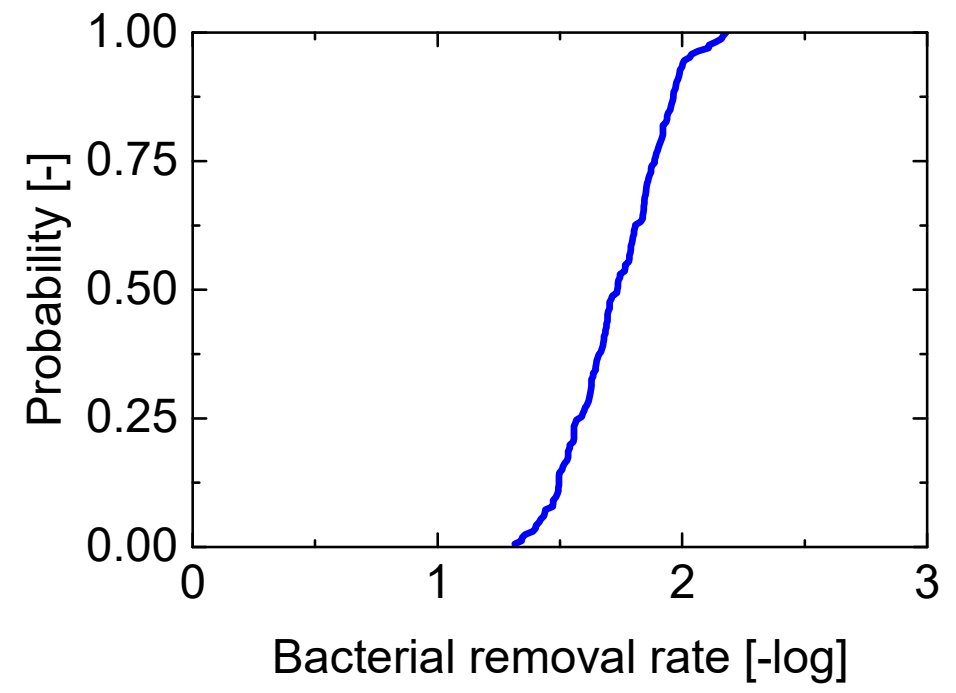

Fig. 5 

Nagasaki University, 1-14 Bunkyo-machi, Nagasaki 852-8521, Japan

${ }^{3}$ Nanyang Environment \& Water Research Institute (NEWRI), Nanyang Technological University (NTU), 1 Cleantech Loop, CleanTech One, Singapore 637141, Singapore 


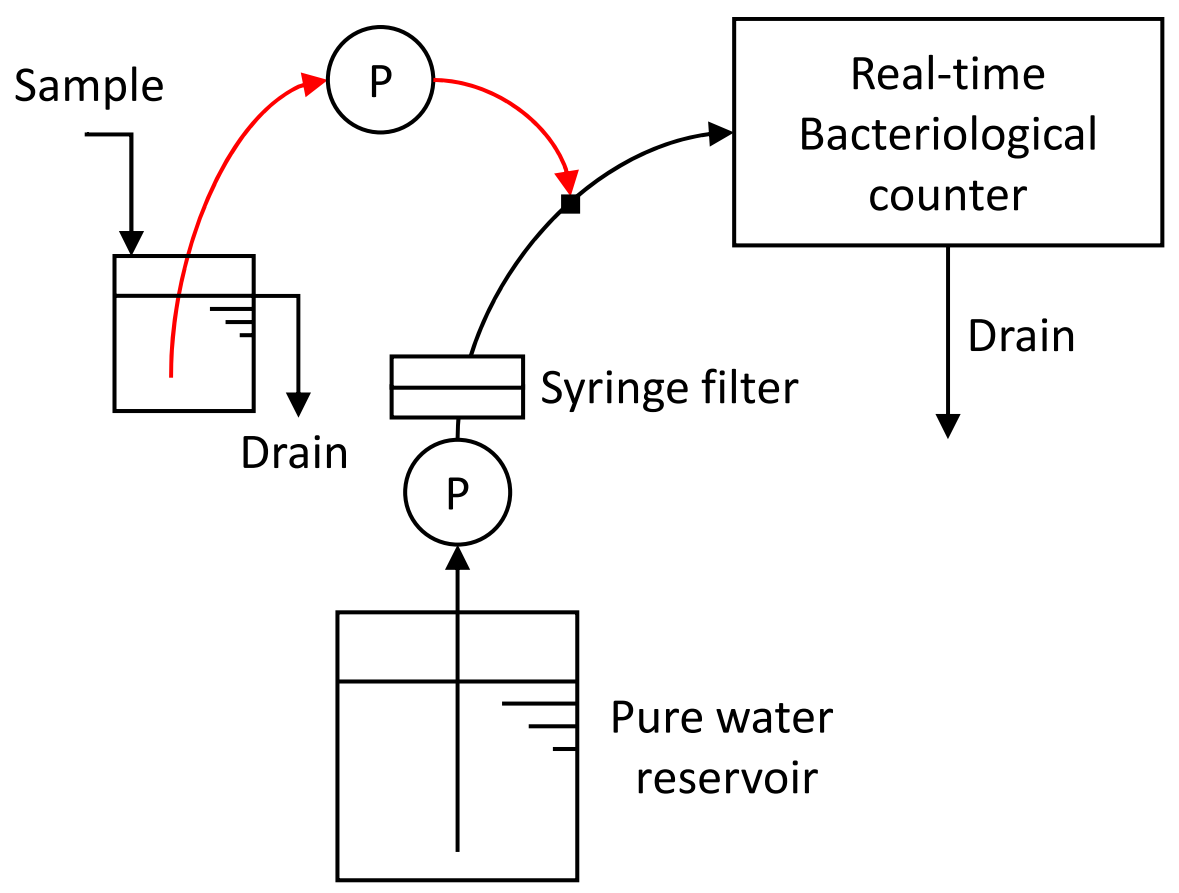

Fig. S1 - Schematic flow diagram of the dilution system for a real-time bacteriological counter. 

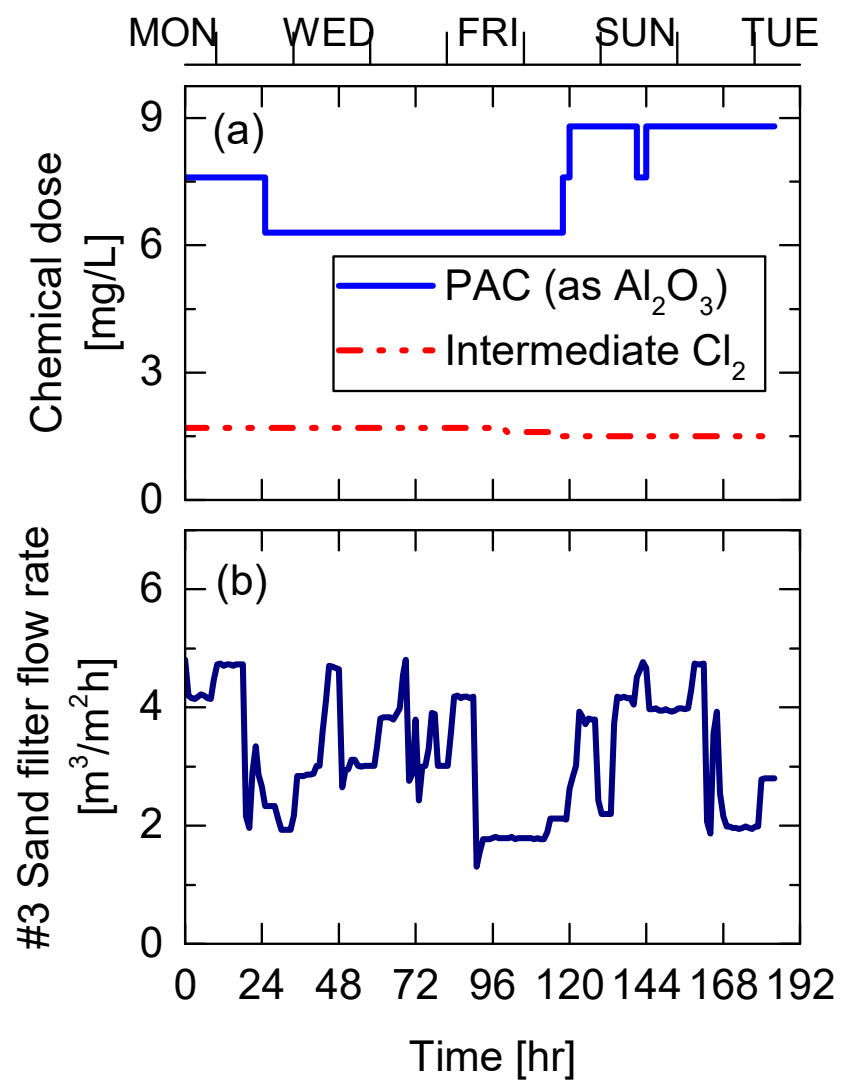

Fig. S2 - Water treatment system operating data: (a) chemical dose, and (b) flow rate of sand filter \#3. 

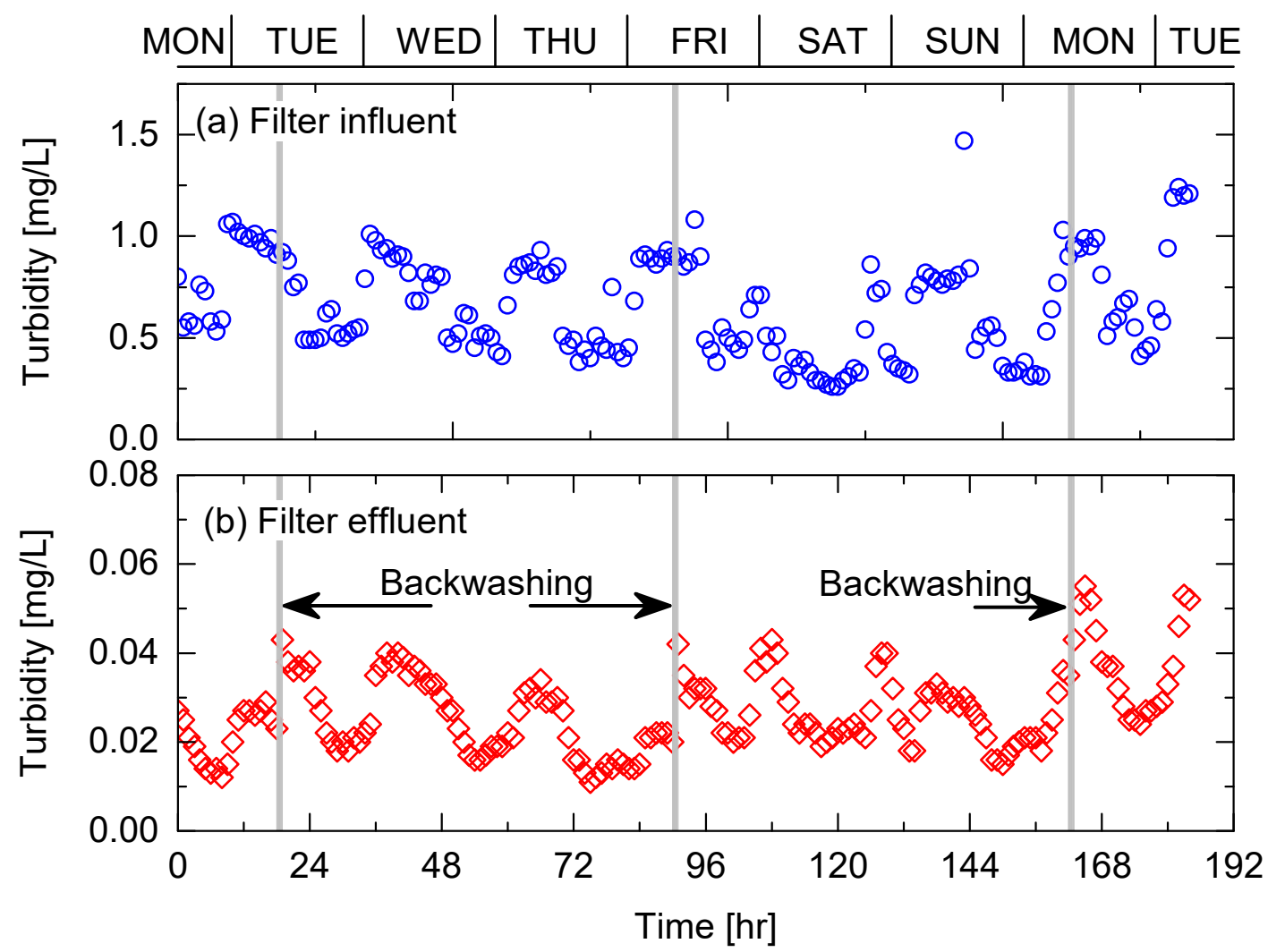

Fig. S3 - Online-monitored turbidity (plot every one hour) in the (a) filter influent and (b) filter effluent. Turbidity is expressed in units of $\mathrm{mg} / \mathrm{L}$, as per the turbidity standard in Japan. Backwashing was conducted for one hour at 18-19, 90-91, and 162-163 hrs. Turbidity in the filter influent and effluent was monitored online using an online surface scattering light turbidity analyzer (AN450A, Hitachi High-Tech Solutions Co., Tokyo, Japan) and an online laser light turbidity analyzer (AN455A, Hitachi High-Tech Solutions Co., Tokyo, Japan), respectively. 
Table S1 - Manual grab sampling data during the full-scale performance test.

\begin{tabular}{|c|c|c|c|c|c|c|}
\hline Time [h] & & 17 & 41 & 65 & 89 & 184 \\
\hline \multicolumn{7}{|l|}{ Filter influent } \\
\hline $\begin{array}{l}\text { Total direct bacterial count } \\
\text { (epi-fluorescence) }\end{array}$ & {$\left[\times 10^{5}\right.$ counts $\left./ \mathrm{mL}\right]$} & $\begin{array}{l}5.2 \\
\pm 0.1\end{array}$ & $\begin{array}{l}2.7 \\
\pm 0.2\end{array}$ & $\begin{array}{l}4.6 \\
\pm 0.2\end{array}$ & $\begin{array}{l}5.0 \\
\pm 0.4\end{array}$ & $\begin{array}{l}8.2 \\
\pm 0.5\end{array}$ \\
\hline $\begin{array}{l}\text { Alive direct bacterial count } \\
\text { (epi-fluorescence) }\end{array}$ & {$\left[\times 10^{5}\right.$ counts $\left./ \mathrm{mL}\right]$} & 1.3 & 0.8 & 1.1 & 1.0 & 2.6 \\
\hline Flow cytometry & {$\left[\times 10^{5}\right.$ counts $\left./ \mathrm{mL}\right]$} & $\begin{array}{l}0.66 \\
\pm 0.05\end{array}$ & $\begin{array}{l}0.88 \\
\pm 0.19\end{array}$ & $\begin{array}{l}0.97 \\
\pm 0.08\end{array}$ & $\begin{array}{l}0.85 \\
\pm 0.06\end{array}$ & $\begin{array}{l}1.64 \\
\pm 0.14\end{array}$ \\
\hline PCA & {$[\mathrm{CFU} / \mathrm{mL}]$} & 29 & 55 & 26 & 20 & 77 \\
\hline HPC & {$[\mathrm{CFU} / \mathrm{mL}]$} & N.A. & N.A. & 1300 & 650 & 1700 \\
\hline Online bacterial count & {$\left[\times 10^{5}\right.$ counts $\left./ \mathrm{mL}\right]$} & 8.9 & 6.4 & 4.8 & 4.3 & 4.3 \\
\hline \multicolumn{7}{|l|}{ Filter effluent } \\
\hline $\begin{array}{l}\text { Total direct bacterial count } \\
\text { (epi-fluorescence) }\end{array}$ & {$\left[\times 10^{4}\right.$ counts $\left./ \mathrm{mL}\right]$} & $\begin{array}{l}6.3 \\
\pm 0.6\end{array}$ & $\begin{array}{l}9.2 \\
\pm 0.5\end{array}$ & $\begin{array}{l}8.5 \\
\pm 0.9\end{array}$ & $\begin{array}{l}7.6 \\
\pm 0.4\end{array}$ & $\begin{array}{l}13.6 \\
\pm 0.9\end{array}$ \\
\hline $\begin{array}{l}\text { Alive direct bacterial count } \\
\text { (epi-fluorescence) }\end{array}$ & {$\left[\times 10^{4}\right.$ counts $\left./ \mathrm{mL}\right]$} & 2.4 & 4.5 & 2.5 & 4.0 & 1.5 \\
\hline Flow cytometry & {$\left[\times 10^{4}\right.$ counts $\left./ \mathrm{mL}\right]$} & $\begin{array}{l}0.40 \\
\pm 0.03\end{array}$ & $\begin{array}{l}0.29 \\
\pm 0.02\end{array}$ & $\begin{array}{l}0.32 \\
\pm 0.04\end{array}$ & $\begin{array}{l}0.21 \\
\pm 0.06\end{array}$ & $\begin{array}{l}1.03 \\
\pm 0.17\end{array}$ \\
\hline PCA & {$[\mathrm{CFU} / \mathrm{mL}]$} & 0 & 0 & 0 & 0 & 0 \\
\hline HPC & {$[\mathrm{CFU} / \mathrm{mL}]$} & N.A. & N.A. & 0 & 0 & 0 \\
\hline Online bacterial count & {$\left[\times 10^{4}\right.$ counts $\left./ \mathrm{mL}\right]$} & 0.62 & 0.92 & 0.70 & 0.49 & 1.26 \\
\hline
\end{tabular}

